\title{
THE PEACH SAWFLY: A CORRECTION.
}

By B. H. Walden, Agricultural Experiment Station, New Haven, Conn.

Following the article, Notes on a New Sawfly Attacking Peach, in Bulletin 67 of the Bureau of Entomology, page 87, is a note regarding the occurrence of this insect in New Jersey and Pennsylvania.- These records do not apply to the peach sawfly, but to the maple stem-borer, Priophorus acericaulis MacG., and were given in a discussion following an account of the latter insect by Dr. Britton (see page 94).

The peach sawfly, Pamphilius persicum MacG., promises to become quite a serious pest in Connecticut peach orchards. The owners of the orchard in Yalesville where the insect was first found, sprayed over four thousand peach trees during the past season with arsenate of lead and water, using three pounds in fifty gallons. The larvæ were readily killed and the foliage was not injured by the spray. The sawfly has been found in several places in New Haven county and at a distance of about fifteen miles from where it was first discovered. We have received no record of its occuring outside of the State.

An account of the past season's observations regarding the insect has been published in the seventh annual report of the State Entomologist of Connecticut, p. 285.

\section{NOTES ON PSYLLOBORA 20-MACULATA SAY.}

By JoHn J. Davis, Urbana, Ill.

In bulletin vol. 1, no. 1 (technical series) of the Ohio Agricultural Experiment Station, Mr. C. M. Weed writes of having found the larvæ of Psyllobora 20-maculata on false or blue lettuce, iron-weed, and various kinds of false sunflower, and as these plants were infested with plant lice, he indicates that they may feed upon them, although no observations to that effect were made.

June 23, 1906, I found the larvæ and one pupa of this Coccinellid on the foliage of the common wild phlox (Phlox divaricata) at Homer, Ill. None of these plants were infested with plant-lice and these larvæ were observed feeding upon the epidermal tissues of the leaves.

Mr. Weed gave the length of the pupal life as being about a fortnight, while in my records I found the pupal period to be six days. Mr. Weed's observations were made in the fall and mine were made in the spring. These differences in the lengths of the pupal period may be accounted for by reason of the difference of the effective temperatures in the spring and fall, development being more rapid in the latter than in the former, even though the temperatures may be the same. 


\section{$2 \mathrm{BHL}$ Biodiversity Heritage Library}

Davis, John J. 1908. "Notes on Psyllobora 20-maculata Say." Journal of economic entomology 1(2), 160-160. https://doi.org/10.1093/jee/1.2.160a.

View This Item Online: $\underline{\text { https://www.biodiversitylibrary.org/item/37189 }}$

DOI: https://doi.org/10.1093/jee/1.2.160a

Permalink: https://www.biodiversitylibrary.org/partpdf/325848

\section{Holding Institution}

New York Botanical Garden, LuEsther T. Mertz Library

\section{Sponsored by}

The LuEsther T Mertz Library, the New York Botanical Garden

\section{Copyright \& Reuse}

Copyright Status: NOT_IN_COPYRIGHT

This document was created from content at the Biodiversity Heritage Library, the world's largest open access digital library for biodiversity literature and archives. Visit BHL at https://www.biodiversitylibrary.org. 